\title{
Pengaruh Pemberian Tempe Dedak terhadap Performa Ayam Broiler
}

\author{
The Effect of Feeding Rice Bran Tempeh on the Performance of Broilers
}

\author{
Isa Nur Fitriyani, Urip Santoso* dan Tris Akbarillah \\ Jurusan Peternakan, Fakultas Pertanian, Universitas Bengkulu \\ Jalan Raya W. R Supratman, Kandang Limun, Bengkulu, 38371 A \\ *Corresponding e-mail: santoso@unib.ac.id
}

\begin{abstract}
This study aims to evaluate the effect of feeding rice bran tempeh on the performance of broiler chickens. The study used a completely randomized design with 5 treatment groups consisting of 4 replications in each treatment. Each replication contains 4 broilers. The 5 treatment groups were as follows: 1) Broilers fed diet containing $5 \%$ rice bran as a control (P0); 2) broilers fed diet with $5 \%$ rice bran tempeh (P1); 3 ) broiler fed diet with $8 \%$ rice bran tempeh $(\mathrm{P} 2)$; 4$)$ broilers fed diet with $11 \%$ rice bran tempeh $(\mathrm{P} 3)$ and; 4$)$ broilers fed diet with $14 \%$ rice bran tempeh $(\mathrm{P} 4)$. The results showed that the administration of rice bran tempeh had no significant effect $(\mathrm{P}>0.05)$ on feed intake,body weight gain and feed conversion ratio in broilers. It can be concluded that rice bran tempeh can be given in broilerdiet up to $14 \%$.
\end{abstract}

Key words: Rice bran tempeh, body weight gain, feed conversion ratio, broiler chicken

\begin{abstract}
ABSTRAK
Penelitian ini bertujuan untuk mengevaluasi pengaruh pemberian tempe dedak terhadap performa ayam broiler. Penelitian menggunakan Rancangan Acak Lengkap (RAL) dengan 5 kelompok perlakuan yang terdiri 4 ulangan pada setiap perlakuan. Setiap ulanganberisi 4 ekor ayam broiler. Adapun ke 5 perlakuan itu adalah sebagai berikut: 1) Broiler diberi pakan yang mengandung dedak sebagai kontrol (P0); 2) broiler diberi pakan mengandung 5\% tempe dedak (P1);3) broiler diberi pakan mengandung $8 \%$ tempe dedak (P2); 4) broiler diberi pakan mengandung 11\% tempe dedak (P3) dan; 4) broiler diberi pakan mengandung 14\% tempe dedak (P4). Hasil penelitian menunjukkan bahwa pemberian tempe dedak berpengaruh tidak nyata $(\mathrm{P}>0,05)$ terhadap konsumsi ransum, pertambahan berat badan dan konversi pakan pada ayam broiler. Dapat disimpulkan bahwa tempe dedak dapat diberikan pada pakan broiler sampai dengan $14 \%$.
\end{abstract}

Kata kunci : Tempe dedak, pertambahan berat badan, konversi pakan, ayam broiler

\section{PENDAHULUAN}

Dedak padi merupakan hasil samping dari penggilingan padi, yang dimanfaatkan sebagai sumber energi pada unggas. Kelemahan dedak padi ini antara lain tingginya serat kasar (Hartadi et al., 2005) dan asam fitat (Wahyuni et al., 2011). Serat kasar yang tinggi dapat mengganggu kecernaan zat nutrisi (Putrawan dan Soerawidjaja, 2007). Fosfor dalam dedak padi $80 \%$-nya terikat dalam bentuk fitat, sehingga sulit dicerna. Fosfor dalam bentuk fitat dapat mengganggu pertumbuhan tulang dan kenaikan berat tubuh ayam. Ayam memerlukan 0,4-0,5 fosfor di dalam pakan.
Oleh karena fosfor dalam dedak terikat dalam bentuk senyawa komples, yaitu asam fitat, maka ketersediaannya bagi unggas sangat rendah. Asam fitat juga mengikat ion kalsium, besi dan seng, sehingga membentuk senyawa komples mineral-fitat yang sulit larut dalam air. Selain itu, asam fitat juga sangat mudah bereaksi dengan protein membentuk fitat- protein yang kompleks, sehingga menurunkan kelarutan protein.

Untuk menghidrolisis fitat diperlukan enzim fitase yang dapat dihasilkan oleh mikroba tertentu, atau dapat difermentasi. Fermentasi dapat meningkatkan bahan pakan, karena pada fermentasi terjadi perubahan zat senyawa-senyawa organik (karbohidrat, lemak, protein, serat kasar) baik dalam 
keadaan aerob maupun anaerob, melalui kerja enzim yang dihasilkan oleh mikroba (Sukaryana, 2011). Fermentasi bahan pakan dapat memperbaiki nilai gizi seperti meningkatnya kadar protein dan protein terlarut dalam air serta dapat memecah protein menjadi senyawa yang lebih sederhana seperti peptide dan asam amino (Susi, 2012).

Hardini (2010) mengugkapkan bahwa fermentasi menghasilkan bahan kering, protein kasar dan protein terlarut yang lebih tinggi. Selanjutnya dinyatakan asam amino meningkat dari $7,36 \%$ menjadi $12,37 \%$ dan protein meningkat dari $12,9 \%$ menjadi $18,82 \%$. Stodolak et al. (2008) melaporkan bahwa fermentasi dengan ragi tempe mampu menurunkan tripsin inhibitor dan fitat masing-masing sebanyak $95 \%$ dan $22 \%$ serta meningkatkan ketersediaan protein. Penurunan fitat dan meningkatnya ketersediaan protein tersebut akan meningkatkan mutu bahan pakan, sehingga kegunaan bahan baku tersebut meningkat. Menurut Koni et al (2008) produk biji asam yang difermentasi dengan Rhyzopus oligosparus dapat digunakan sampai dengan $22,5 \%$ pada broiler.

Sangat sedikit penelitian tentang tempe dedak, padahal ragi tempe harganya lebih murah dari pada inokulum murni seperti Rhizopus oligosporus dan Rhizopus orizae. Berdasarkan uraikan tersebut di atas, penelitian ini bertujuan untuk mengevaluasi pengaruh penggunaan dedak yang difermentasi dengan ragi tempe terhadap performa ayam broiler.

\section{MATERI DAN METODE}

Penelitian ini dilaksanakan selama 2 bulan, berlokasi di Laboratorium dan Kandang di Jurusan Peternakan Fakultas Pertanian Universitas Bengkulu.

\section{Pembuatan Tempe Dedak}

Dedak ditambahkan air dengan perbandingan 1:1, dikukus selama 30 menit, dan kemudian didinginkan. Setelah dingin dedak ditaburi ragi tempe sebanyak $2 \mathrm{~g} / \mathrm{kg}$, dibungkus dengan plastik ukuran $1 \mathrm{~kg}$ dengan isi 750 gram. Dedak difermentasi selama 3 hari. Setelah fermentasi sempurna, tempe dedak kemudian dijemur sampai kering dan disimpan dalam plastik sebelum diberikan pada broiler.

\section{Hewan Percobaan, Pakan, dan Analisis Data}

Kandang broiler, petak kandang (unit percobaan), brooder, tempat pakan, tempat air minum dan peralatan kandang lainnya disanitasi. Setelah kering, dinding dan lantai kandang serta petak kandang dikapur. Ukuran petak kandang adalah 1 x 0,65 x 0,65 $\mathrm{m}$. alas petak kandang berupa sekam dengan ketebalan $5 \mathrm{~cm}$. Anak ayam yang baru tiba ditempatkan pada brooder dengan alas sekam padi (ketebalan $5 \mathrm{~cm}$ ) yang di atasnya dilapisi dengan kertas koran, dan diberi air gula untuk mengurangi stress akibat perjalanan. Anak ayam yang baru tiba dikenalkan dengan pakan dan air minum. Suhu brooder diatur sesuai dengan standar pemeliharaan untuk ayam. Pada umur 4 dan 21 hari ayam broiler divaksinasi ND.

Penelitian ini menggunakan Rancangan Acak Lengkap (RAL). Sebanyak 80 ekor broiler umur15 hari didistribusikan ke dalam 5 kelompok perlakuan dengan 4 ulangan untuk setiap perlakuan. Setiap ulangan berisi 4 ekor ayam broiler. Adapun ke 5 kelompok perlakuan itu adalah sebagai berikut.

a) broiler diberi pakan yang mengandung $5 \%$ dedak sebagai kontrol (P0);

b) broiler diberi pakan yang mengandung $5 \%$ tempe dedak (P1);

c) broiler diberi pakan yang mengandung $8 \%$ tempe dedak (P2);

d) broiler diberi pakan yang mengandung $11 \%$ tempe dedak (P3) dan;

e) broiler diberi pakan yang mengandung tempe dedak (P4).

Pada umur 1-14 hari broiler diberi pakan komersial dan dilanjutkan dengan pakan percobaan. Broiler dipelihara sampai dengan umur 35 hari. Susunan pakan percobaan disajikan pada Tabel 1. Pakan 
percobaan untuk $\mathrm{P} 0, \mathrm{P} 1, \mathrm{P} 2, \mathrm{P} 3$ dan $\mathrm{P} 4$ mengandung protein masing-masing sebesar $19,69 \%, 19,75 \%, 19,77 \%, 19,80 \%$ dan $19,82 \%$. Berat badan, pertambahan berat badan, konsumsi pakan dan konversi pakan diukur setiap minggu. Pakan dan air minum diberikan ad libitum. Semua data dianalisis varians dan jika berbeda nyata diuji lanjut dengan Duncan's Multiple Range Test.

Tabel 1. Susunan pakan penelitian

\begin{tabular}{llllll}
\hline Bahan Pakan (\%) & P0 & P1 & P2 & P3 & P4 \\
\hline Jagung & 57 & 57 & 54 & 51 & 48 \\
Kosentrat & 34,2 & 34,2 & 34,2 & 34,2 & 34,2 \\
Dedak & 5 & 0 & 0 & 0 & 0 \\
Tempe dedak & - & 5 & 8 & 11 & 14 \\
Mineral mix & 1,7 & 1,7 & 1,7 & 1,7 & 1,7 \\
Top mix & 0,5 & 0,5 & 0,5 & 0,5 & 0,5 \\
Garam & 0,1 & 0,1 & 0,1 & 0,1 & 0,1 \\
Minyak & 2 & 2 & 2 & 2 & 2 \\
Total & 100 & 100 & 100 & 100 & 100 \\
Kandungan Nutrisi & & & & & \\
Protein (\%) & 19,69 & 19,75 & 19,77 & 19,80 & 19,82 \\
ME (kkal) & 3137,07 & 3086,37 & 3139,65 & 3192,93 & 3246,21 \\
Ca (\%) & 0,95 & 0,96 & 0,96 & 0,97 & 0,98 \\
P (\%) & 0,68 & 0,63 & 0,63 & 0,62 & 0,62 \\
\hline
\end{tabular}

Keterangan :

$\mathrm{P} 0=$ broiler diberi pakan yang mengandung 5\% dedak sebagai kontrol;

$\mathrm{P} 1$ = broiler diberi pakan yang mengandung 5\% tempe dedak;

$\mathrm{P} 2=$ broiler diberi pakan yang mengandung $8 \%$ tempe dedak;

P3 = broiler diberi pakan yang mengandung $11 \%$ tempe dedak dan;

$\mathrm{P} 4$ = broiler diberi pakan yang mengandung tempe dedak.

\section{HASIL DAN PEMBAHASAN}

\section{Berat Badan}

Hasil sidik ragam menunjukkan bahwa pemberian tempe dedak berpengaruh tidak nyata $(\mathrm{P}>0,05)$ terhadap beratbadan ayam broiler (Tabel 2). Hasil penelitian menunjukkan bahwa pemberian tempe dedak sampai dengan $14 \%$ dapat diberikan sebagai pengganti jagung.

Meskipun tidak berpengaruh nyata, namun terdapat kecenderungan bahwa pemberian tempe dedak cenderung mempunyai berat badan yang lebih tinggi jika dibandingkan dengan kontrol. Berdasarkan hal ini maka diduga bahwa tempe dedak dapat diberikan lebih dari $14 \%$. Hasil analisis kandungan asam fitat pada dedak adalah sebanyak $6,150 \%$ dan pada tempe dedak sebesar $3,975 \%$. Jadi, tempe dedak menurunkan asam fitat sebesar $35,3 \%$.
Penurunan kadar asam fitat diduga sebagai salah satu faktor meningkatnya berat badan pada broiler yang diberi tempe dedak. Selain penurunan asam fitat, diduga terjadi peningkatan ketersediaan protein. Selain itu, hasil analisis korelasi-regresi antara konsumsi dan berat diperoleh nilai $\mathrm{r}=0,98$ dengan persamaan $\mathrm{Y}=-1127,59+2,76 \mathrm{X}$, dimana $\mathrm{Y}$ adalah berat badan dan $\mathrm{X}$ adalah konsumsi pakan. Hal ini berarti peningkatan berat badan juga disebabkan oleh peningkatan konsumsi pakan. Munira et al. (2016) menemukan bahwa pemberian tempe dedak cenderung meningkatkan berat badan pada ayam kampung super. Suhenda et al. (2010) menemukan bahwa pemberian tempe dedak meningkatkan berat badan pada ikan mas. Selanjutnya ditemukan bahwa terjadi peningkatan retensi protein. Hal ini menunjukkan bahwa peningkatan berat badan disebabkan juga oleh peningkatan retensi protein dalam tubuh. 
Tabel 2. Pengaruh pemberian tempe dedak terhadap berat badan ayam broiler

\begin{tabular}{ccccccc}
\hline Minggu & P0 & P1 & P2 & P3 & P4 & P \\
\hline & & $\ldots \ldots \ldots \ldots \ldots$ & gram/ekor & $\ldots \ldots \ldots \ldots \ldots$ & & \\
2 & 551,25 & 530,50 & 532,50 & 531,00 & 537,50 & 0,939 \\
3 & 786,88 & 770,00 & 797,50 & 775,13 & 787,50 & 0,951 \\
4 & 1130,63 & 1101,25 & 1113,75 & 1096,25 & 1209,38 & 0,562 \\
5 & 1463,75 & 1456,25 & 1470,00 & 1513,75 & 1627,50 & 0,398 \\
\hline
\end{tabular}

$\mathrm{P} 0$ = Broiler diberi pakan yang mengandung dedak sebagai kontrol; P1 = broiler diberi pakan mengandung $5 \%$ tempe dedak; $\mathrm{P} 2=$ broiler diberi pakan mengandung $8 \%$ tempe dedak (P2); P3 = broiler diberi pakan mengandung $11 \%$ tempe dedak dan; P4 = broiler diberi pakan mengandung $14 \%$ tempe dedak.

Hasil penelitian menunjukkan bahwa sejalan dengan bertambahnya umur maka berat badan semakin meningkat. Hasil tersebut sesuai pendapat Andriyanto et al. (2014) yang menyatakan bahwa dengan bertambahnya umur pada ayam broiler, maka berat badan ayam broiler akan meningkat.

\section{Pertambahan Berat Badan}

Hasil sidik ragam menunjukkan bahwa pemberian pakan dengan tempe dedak berpengaruh tidak nyata $(\mathrm{P}>0,05)$ terhadap pertambahan berat badan (Tabel 3).
Meskipun berpengaruh tidak nyata, terdapat kecenderungan bahwa semakin tinggi pemberian tempe dedak, maka semakin tinggi pula pertambahan berat badan ayam broiler.

Kecenderungan ini disebabkan antara lain dikarenakan zat antinutrisi dalam tempe dedak menurun, meningkatnya ketersediaan protein, mineral, vitamin dan zat gizi lainnya. Oliveira et al. (2010) menemukan bahwa dedak yang difermentasi menurunkan asam fitat tetapi meningkatkan abu, protein dan kecernaan asam amino.

Tabel 3. Pengaruh pemberian tempe dedak terhadap pertambahan berat badan ayam broiler

\begin{tabular}{ccccccc}
\hline Minggu & P0 & P1 & P2 & P3 & P4 & P \\
\hline & & $\ldots \ldots \ldots \ldots \ldots$ & gram/ekor & $\ldots \ldots \ldots \ldots$ & & \\
3 & 235,63 & 237,50 & 265,00 & 246,88 & 250,00 & 0,825 \\
4 & 343,75 & 331,25 & 316,25 & 318,13 & 421,88 & 0,145 \\
5 & 333,13 & 355,00 & 356,25 & 417,50 & 418,13 & 0,233 \\
Total & 912,50 & 923,63 & 937,50 & 982,50 & 1090,00 & 0,189 \\
\hline
\end{tabular}

$\mathrm{P} 0=$ Broiler diberi pakan yang mengandung dedak sebagai kontrol; $\mathrm{P} 1$ = broiler diberi pakan mengandung $5 \%$ tempe dedak; $\mathrm{P} 2$ = broiler diberi pakan mengandung $8 \%$ tempe dedak $(\mathrm{P} 2)$; P3 = broiler diberi pakan mengandung $11 \%$ tempe dedak dan; P4 = broiler diberi pakan mengandung $14 \%$ tempe dedak.

Peningkatan kadar abu dan protein serta kecernaan asam amino merupakan salah satu faktor penyebab peningkatan pertambahan berat badan. Penurunan asam fitat akan meningkatkan ketersediaan mineral, yang berarti akan mendukung metabolisme zat gizi dan pertumbuhan tulang pada ayam broiler. Kecenderungan peningkatan pertambahan berat badan itu sangat menguntungkan bagi peternak, karena dapat meningkatkan keuntungan yang diperolehnya dengan catatan apabila konversi pakan dan biaya pakan relatif sama. Munira et al. (2016) menemukan bahwa pemberian tempe dedak cenderung meningkatkan pertambahan berat badan pada ayam kampung super. Suhenda et al. (2010) menemukan bahwa pemberian tempe dedak meningkatkan pertambahan berat badan pada ikan mas.

\section{Konsumsi Pakan}

Hasil sidik ragam menunjukan bahwa pemberian pakan dengan tempe dedak (dedak fermentasi) berpengaruh tidak nyata $(\mathrm{P}>0,05)$ terhadap konsumsi pakan ayam broiler (Tabel 4). Meskipun berpengaruh tidak nyata, terdapat kecenderungan peningkatan konsumsi pakan pada broiler yang diberi $14 \%$ tempe dedak. 
Tabel 4. Pengaruh tempe dedak terhadap konsumsi pakan pada ayam broiler

\begin{tabular}{ccccccc}
\hline Minggu & P0 & P1 & P2 & P3 & P4 & P \\
\hline & & $\ldots \ldots \ldots \ldots \ldots$ & gram/ekor & $\ldots \ldots \ldots \ldots$. & & \\
3 & 598,38 & 569.69 & 591,25 & 588,13 & 596,25 & 0,813 \\
4 & 896,88 & 853,75 & 865,94 & 823,75 & 956,25 & 0,613 \\
5 & 673,13 & 624,38 & 703,13 & 716,88 & 948,13 & 0,185 \\
Kumulatif & 2169,38 & 2047,83 & 2160,35 & 2128,75 & 2500,63 & 0,340 \\
\hline
\end{tabular}

P0 = Broiler diberi pakan yang mengandung dedak sebagai kontrol; P1 = broiler diberi pakan mengandung $5 \%$ tempe dedak; $\mathrm{P} 2=$ broiler diberi pakan mengandung $8 \%$ tempe dedak (P2); P3 = broiler diberi pakan mengandung $11 \%$ tempe dedak dan; P4 = broiler diberi pakan mengandung $14 \%$ tempe dedak.

Munira et al. (2016) menemukan bahwa penambahan $10 \%$ tempe dedak cenderung meningkatkan konsumsi pakan pada ayam kampung super. Hal ini menunjukkan bahwa terjadi kecenderungan peningkatan palatabilitas pada broiler yang diberi $14 \%$ tempe dedak. Belum diketahui faktor penyebab kecenderungan peningkatan palatabilitas pada broiler, mengingat ayam broiler sebagaimana unggas lain kurang mampu merasakan pakan yang dikonsumsinya. Diduga pemberian $14 \%$ tempe dedak meningkatkan sensivisitas syaraf yang mengatur konsumsi pakan pada broiler.

Semakin umur bertambah maka ayam broiler maka semakin tinggi konsumsiyang diperlukan ayam broiler. Hal tersebut sama seperti pendapat yang dikemukakan oleh Zulfanita et al. (2011) yang menyatakan bahwa semakin bertambahnya usia ayam broiler, sehingga konsumsi pakan akan bertambah untuk memenuhi kebutuhan ayam tersebut.

\section{Konversi Pakan}

Hasil sidik ragam menunjukkan bahwa pemberian pakan dengan tempededak berpengaruh tidak nyata ( $\mathrm{P}>0,05)$ (Tabel 5). Meskipun berpengaruh tidak nyata, pemberian tempe dedak cenderung menurunkan konversi pakan. Salah satu senyawa dalam dedak yang dapat menurunkan konversi pakan adalah octacosanol.

Tabel 5. Pengaruh tempe dedak terhadap konversi pakan pada ayam broiler

\begin{tabular}{ccccccc}
\hline Minggu & P0 & P1 & P2 & P3 & P4 & P \\
\hline 3 & 2,58 & 2,40 & 2,55 & 2,44 & 2,40 & 0,897 \\
4 & 2,63 & 2,60 & 2,80 & 2,62 & 2,29 & 0,469 \\
5 & 2,11 & 1,82 & 1,93 & 1,73 & 2,24 & 0,590 \\
Kumulatif & 2,40 & 2,23 & 2,29 & 2,17 & 2,28 & 0,741
\end{tabular}

P0 = Broiler diberi pakan yang mengandung dedak sebagai kontrol; P1 = broiler diberi pakan mengandung 5\% tempe dedak; $\mathrm{P} 2=$ broiler diberi pakan mengandung $8 \%$ tempe dedak $(\mathrm{P} 2)$; $\mathrm{P} 3$ = broiler diberi pakan mengandung $11 \%$ tempe dedakdan; $\mathrm{P} 4$ = broiler diberi pakan mengandung $14 \%$ tempe dedak.

Selain itu peningkatan retensi protein (Suhenda et al., 2010) dan kecernaan asam amino (Oliveira et al., 2010) juga memberikan kontribusi terhadap penurunan konversi pakan. Peng et al. (2016) menemukan bahwa octacosanol yang diekstrak dari dedak padi cenderung menurunkan konversi pakan. Diduga fermentasi meningkatkan ketersediaan octacosanol sehingga dapat memberikan kontribusi kepada penurunan konversi pakan.Kecenderungan ini sangat menguntung bagi peternak, karena konversi pakan jika diimbangi oleh biaya pakan yang relatif sama akan menghasilkan keuntungan yang lebih tinggi. 


\section{KESIMPULAN}

Berdasarkan hasil penelitian maka tempe dedak dapat diberikan pada ayam broiler sampai dengan $14 \%$ sebagai pengganti jagung tanpa menurunkan performanya.

\section{DAFTAR PUSTAKA}

Andriyanto, A. S. Satyaningtijas, R. Yufiandri, R. Wulandari, V. M. Darwin, dan S. N. A. Siburian. 2014. Performa dan kecernaan pakan ayam broiler yang diberi hormon testosteron dengan dosis bertingka. Jurnal Fakultas Kedokteran Hewan IPB. Bogor.

Hardini, D. 2010. The nutrient evaluation of fermented rice bran as poultry feed. International Journal of Poultry Science. 9 (2): 152-154.

Hartadi, H., S. Reksohadiprodjo dan A. D. Tillman. 2005. Tabel Komposisi Pakan Untuk Indonesia. Gadjah Mada University Press, Yogyakarta.

Koni, T. N. I, A. Paga, dan A. Jahemat. Respon Broiler terhadap Ransum Biji Asam. 2008. Jurnal Ilmu Ternak. 13 (1) : 48-49.

Munira, S., L. O. Nafiu dan A. M. Tasse. 2016. Performans ayam kampung super pada pakan yang disubtitusi dedak padi fermentasi dengan fermentor yang berbeda. JITRO, 3 (2): 20-29.

Oliveira, M. D. S., Feddern, V., Kupski, L., Cipolatti, E. P., Badiale-Furlong, E., \& de Souza-Soares, L. A. 2010. Physico-chemical characterization of fermented rice bran biomass Caracterización fisico-química de la biomasa del salvado de arroz fermentado. CyTA-Journal of Food. 8 (3): 229-236.
Putrawan, I.D.G.A., dan T.H.Soerawidjaja. 2007. Stabilisasi dedak padi melalui pemasakan ekstrusif. Jurnal Teknik Kimia Indonesia. 6 (3) : 681- 688.

Stodolak, B. and A. Starzyńska-Janiszewska. 2008. The influence of tempeh fermentation and conventional cooking on anti-nutrient level and protein bioavailability (in vitro test) of grass-pea seeds. Journal of the Science of Food and Agriculture. 88 (13): 2265-2270.

Sukaryana Y., U. Atmomarsono, V. D. Yunianto, E. Supriyatna. 2011. Peningkatan nilai kecernaan protein kasar dan lemak kasar produk fermentasi campuran bungkil inti sawit dan dedak padi pada broiler. JITP. 1(3): 167-172.

Suhenda, N., R. Samsudin dan I. Melati. 2010. Peningkatan kualitas bahan nabati (dedak padi dan dedak polar) melalui proses fermentasi (Rhyzopus ologosporus) dan penggunaannya dalam pakan ikan (Cyprinus carpio). Prosiding Forum Inovasi Teknologi Akuakultur.

Susi, S. 2012. Komposisi kimia dan asam amino pada tempe kacang nagara (Vigna unguiculata ssp. cylindrica). Agroscientie. 19 (1) :28 -36.

Wahyuni, S., D. C. Budinuryanto, H. Supratman dan Suliantari. 2011. Respon broiler terhadap pemberiaan ransum mengandung dedak padi fermentasi oleh kapang Aspergillus ficuum. Jurnal Ilmu Ternak. 10 (1) : 26-31.

Zulfanita, R. Eny dan D. P. Utami. 2011. Pembatasan ransum berpengaruh terhadap pertambahan bobot badan ayam broiler pada periode pertumbuhan. Jurnal Ilmu-ilmu Pertanian. 7 (1) : 59-67. 